\title{
Formulating 'principles of procedure' for the foreign language classroom: a framework for process model language curricula
}

\section{Luis S. Villacañas de Castro}

To cite this article: Luis S. Villacañas de Castro (2015): Formulating 'principles of procedure' for the foreign language classroom: a framework for process model language curricula, Journal of Curriculum Studies, DOI: 10.1080/00220272.2015.1114149

To link to this article: http://dx.doi.org/10.1080/00220272.2015.1114149

曲 Published online: 23 Nov 2015.

Submit your article to this journal $[\pi$

Q View related articles ¿

View Crossmark data 


\title{
Formulating 'principles of procedure' for the foreign language classroom: a framework for process model language curricula
}

\author{
Luis S. Villacañas de Castro \\ Facultat de Magisteri, Department of Language and Literature Education, Universitat de València, València, \\ Spain
}

\begin{abstract}
This article aims to apply Stenhouse's process model of curriculum to foreign language (FL) education, a model which is characterized by enacting principles of procedure which are specific to the discipline which the school subject belongs to. Rather than to replace or dissolve current approaches to FL teaching and curriculum development, this article seeks to improve and enrich communicative and taskbased orientations with an additional criterion for assessing the educational worth of the tasks through which these orientations are developed. Unlike the objectives and competences models, principles of procedure provide an intrinsic justification of school curriculum by enacting the epistemological structure of any given area of knowledge in the educational process. Accordingly, the article will first justify the need to come up with a process model of curriculum for FL education which is built around such principles; then, it will formulate a basic framework that reflects the logical structure, concepts and epistemological perspectives of the language studies, as a first step to allowing these to enter the FL classroom and orient the teaching conducted in it; finally, it will present three tasks whose design was inspired by the abovementioned framework, and which were put into practice with Primary education English as a Foreign Language learners during the 2013-2014 and 2014-2015 academic years.
\end{abstract}

\section{KEYWORDS}

Process model curriculum; principles of procedure; foreign language education; epistemology; pedagogy

\section{Introduction}

As its title suggests, this article aims to make a contribution to the design and development of a process model of curriculum (Elliott, 1991; McKernan, 2008; Stenhouse, 1981) for the foreign language (FL) classroom, a context in which the real impact of process-oriented approaches to education is still hard to ascertain. Whereas, according to Littlewood (2009), this school area has experimented an 'increasing attention not only to the products that we expect learning to achieve [...] and the pedagogy that might lead to these products but also to the processes through which learning takes place' (p. 246), Bolhuis and Voeten (2001) showed that 'only $5 \%$ of the total amount of time was spent on process oriented teaching' 
(p. 846 cited in O'Sullivan, 2007, p. 275), hence also that most language teachers at the time of their survey still made their curricular and pedagogical decisions basing themselves on the importance of the learning outcomes. Independently of the real impact that process curricula have had on FL education, a growing consensus has built up around the idea that the present emphasis on teacher accountability and student testing (Alexander, 2004; Au, 2011; Elliott, 2007; Husch, 2007; Young, 2013) has definitely re-oriented education in general (Fuhrman \& Elmore, 2004) and FL education in particular (Cumming, 2009; Stoks, 1996; Taylor, 2014) towards learning outcomes which have been pushed to the fore, even at the expense of the quality of the educational process. As Tanner (2013) states,

as the high-stakes, standardized tests become the chief metric for national and state assessment of pupil achievement, teacher effectiveness and school quality, there was an about face, from aligning the test to the curriculum to aligning the curriculum to the standards defining the tests. (p. 5)

Against this inertia, this article seeks to rethink and come up with process-oriented forms of curriculum development for the FL subject. It plans to do so by drawing inspiration from Stenhouse's (1981) process model, one which was characterized by enacting principles of procedure which were specific to the discipline which any given subject belonged to. Principles of procedure in education were first discussed by Peters (1966), but the concept was gradually reworked by pedagogues and educators in the teacher-as-researcher (Carr \& Kemmis, 1986, pp. 18-20) and student-as-researcher (Thomson \& Gunter, 2009; Villacañas de Castro, 2015b) tradition of curricular development. In the hands of Stenhouse (1981) and later on, McKernan (2008), the concept was gradually voided of its ethical component and replaced with an epistemological one which brought it closer to recent contributions to curriculum design and development (Young, 2013). However, to the best of my knowledge, neither the translation nor the application of this model to language education in general, and the FL subject in particular, have yet been attempted. Therein lies the original contribution which this article aims to make.

\section{Methodology}

My idea to develop principles of procedure for the FL subject was not motivated by mere academic curiosity but rather by a pressing need to address certain problems in the theory and practice of FL education. As a lecturer and researcher on English as a Foreign Language $(\mathrm{EFL})$ education in the Language and Literature Education Department at the University of Valencia, I have first-hand experience of these problems, as well as indirect experience through discussions with EFL teachers working at both elementary and secondary education levels. These discussions tend to arise every year, usually in the context of my undergraduate and graduate students' practicum placements in primary and secondary schools. This gives me the opportunity to speak with the in-service teachers that supervise them in situ. By listening to their comments, I have come to realize that one of the main difficulties they face is precisely how to justify, in the eyes of their learners, the educational significance and interest of the activities they develop in class (most of them based on their course books), which students often find superficial, boring and meaningless (Villacañas de Castro, 2015a). However, rather than replacing or dissolving current, dominant approaches to EFL teaching and curriculum development (such as communicative and task-based orientations), the main aim of this article is to improve and enrich the latter by providing teachers with an additional 
criterion for assessing the educational worth of the tasks through which these orientations are developed. This is the main role which I attribute to the principles of procedure. As the next section will reveal, unlike the way that curriculum planners resort to either objectives or competences to justify FL education, the justification afforded by principles of procedure rests on what McKernan (2007) described as the 'logical structure' or 'in-built standards' of a given discipline (p. 4), two concepts which, in the context of teaching and learning a FL, would reflect the epistemology of the language sciences and the different perspectives on language which are adopted by the people contributing new knowledge to them. Accordingly, the two basic aims of this article could be summed up in the following way:

- justify the need to come up with a process model of curriculum for FL education built around specific principles of procedure; and

- formulate a basic framework that reflects the logical structure, concepts and epistemological perspectives of this discipline, as a first step to allow these to enter the EFL classroom, and orient the teaching conducted in it.

In order to achieve this aim, my mode of inquiry has followed non-empirical and empirical paths. I first develop a theoretical argument to explicitly identify the limitations of the prevalent models of curriculum design and development (the objectives and the competences models), after which I translate these general shortcomings into FL curricula. Finally, by sharing the empirical results of two collaborative research projects carried out in real classroom settings, I demonstrate the educational potential of concrete curricular tasks that adapted Stenhouse's principles of procedure paradigm to the EFL setting. The empirical phases of the research took place during the 2013-2014 and 2014-2015 academic years, when I invited a group of undergraduate student-teachers, whose final practicum placement I was supervising, to join me in a collaborative action research project focused on the degree to which the aforementioned principles of procedure were applicable to primary EFL classrooms. Through meetings held intermittently during their three-month internship, the student-teachers and I reflected on the principles of procedure for the EFL area and designed specific tasks to carry them out. The student-teachers then put these tasks into practice in the public primary schools where they were doing their placements, with additional guidance from the in-service teachers.

Before a concrete framework, concrete tasks and teaching strategies are presented for the FL subject, I will introduce basic notions about curricular process models and the use of principles of procedure for the educational field. Obviously, the current research literature on curriculum design and FL education is assessed and discussed throughout the article, in line with Stenhouse's original paradigm and the developments to it by John Elliott, James McKernan and others.

\section{Process versus objectives curricula}

Before engaging the more complex definitions which this proposal aims to bring into play, let me clarify that by curriculum, this article does not understand only'the knowledge that pupils are entitled to know', hence something which could be clearly distinct from pedagogy, or 'what teachers do, and get pupils to do' (Young, 2013, p. 111) in order for learning to be attained. Unlike the distinction upheld by this view, this text embraces a wider notion of curriculum, one according to which knowledge and pedagogy imply two separate dimensions 
which nonetheless remain internal to any curriculum design. As defined by Au (2011),'curricular form refers to the organization of meaning and action, including the order in which we are introduced to content and the very form that knowledge itself takes, in the curriculum' ( $p$. 30). Since what is taught and how it is taught are not completely independent dimensions, the demand for coherence still holds between them, so process curricula should include only certain types of pedagogical orientations to remain educationally consistent.

A logical way to approach process-oriented forms of curriculum design and development is to compare them with others that place their focus on pre-specified outcomes or objectives (Apple, 1986; Markee, 1997; Newby, 2004; Nunan, 1988; van Lier, 1996), as is the trend being favoured today in most areas of instruction, including language education. This outcomes-based education, as McKernan (2007) called it, still relies on the objectives curricular model first designed by Tyler as early as in 1949, which provides 'the conventional rationale for curriculum planning' (Cumming, 2009, p. 91). Through this rationale,

educators determine the nature of educational programs first by establishing relevant objectives, then by creating and sequencing appropriate teaching and learning activities, and later evaluating the extent to which students have achieved the objectives intended as a result of participating in the activities prescribed. (p. 91)

Objectives, in addition, tend to be understood as either content objectives or behavioural ones. Whereas the definition of the first kind is self-explanatory - they have to do with what Male and Waters (2014) referred to as 'the possession of information' (p. 215), i.e. knowledge teachers can test their students on - defining behavioural objectives is more complex, especially concerning the extent to which they do or do not involve dimensions of the educational process itself. This issue must be closely discussed: indeed, if the second option were to be the case, then the opposition between process and objectives curricula would not be as watertight as it has normally been described (Newby, 2004; Nunan, 1988; van Lier, 1996). Positions regarding this matter differ depending on whether the distance between both terms is either narrowed or widened. McKernan (2008), for instance, claimed that Tyler's take on objectives, as described in Basic Principles of Curriculum and Instruction, remained completely external to the quality of the process through which the contents should be taught and learnt, hence his claim that Tyler (1949) hypothesized a direct and straightforward relation between content and behavioural objectives, as if the latter were a simple translation of the former. 'One can define an objective with sufficient clarity,'Tyler (1949) originally said, 'if he can describe or illustrate the kind of behavior the student is expected to acquire so that one could recognize such behavior if he saw it' (pp. 59-60, cited in McKernan, 2008, p. 71).

Following from this definition, most curriculum developers have insisted at some point on the idea that curricula must describe objectives as a set of observable behaviours if objectives are really to become useful for educators (Dautry, 2004; de Landsheere \& de Landsheere, 1975; Mager, 1962). Apart from the risk of indulging in teaching to tests (Au, 2011; Tanner, 2013), objectives curricula can also be criticized for ignoring that the relationship between content and behavioural objectives is neither a direct nor a simple one; that, even when the teaching of contents actually leads to the learning of contents, this process may not necessarily result in the expected set of behaviours. That Tyler was so quick to obliterate this distinction - that different kinds of learning processes are required for each outcome - betrays the main risk of this curricular model: favouring teacher-centred, transmission forms of pedagogy (Skourtou, Kourtis-Kazoullis, \& Cummins, 2006) which mistakenly assume that exposing learners to information (i.e. teaching them content) triggers the expected 
behavioural change by itself. The result of this lack of awareness, as Littlewood (2009) mentioned in relation to EFL education, is that objectives curricula generally 'have a lot to say about the outcomes of learning (for example control of selected grammatical structures or communicative functions) but little about the learning and teaching that lead to these outcomes' (p. 251). And, in the same vein, Van Els (2004) conceded that'even if, in principle, foreign language planning [...] covers three major topics of "what to learn/teach", "how to learn/teach", and "under what conditions to learn/teach", [it] usually restricts itself to policy statements with respect to "what?"' (p. 467).

\section{From objectives to competences}

Reformulating content and behavioural objectives as competences (Alarcon Leiva, Hill, \& Frites, 2014; Byrne, Downey, \& Souza, 2013; González-Bernal, 2008; Male \& Waters, 2014; Takayama, 2013) attempted to eliminate this risk. This paradigm brought the educational process closer to the intended behavioural objectives by creating contexts in which the latter could be enacted and attained through practice, precisely in the form of competences. Despite the many definitions one can find of this term, let me first turn to Alarcon Leiva et al.'s (2014) understanding, based on the assumption that 'the learning method constitutes the learning content, to the point that it seems reasonable to sustain a complete indivisibility of one and the other' (p. 574). Pedagogically speaking, this sentence reminds educators that the outcomes one wishes to obtain must be enacted during the learning process itself. 'Competence-based learning implies that knowledge is tacit, situated and gained through experience; the learning that takes place is, therefore, situated temporally, spatially and contextually' (Byrne et al., 2013, pp. 338-339). Thus, if objectives involved pre-specified behavioural aims, then the teaching had to provide the opportunity for students to build these behaviours during the learning process itself rather than simply developing passive reception and memorization skills - the only ones which transmission-based pedagogies exercise.

Accordingly, Male and Waters (2014) no longer defined competences vis-à-vis knowledge - as occurred with content objectives - but as 'the coming together of knowledge, understanding, skills and personal development' (p. 216). In this definition, skills in turn consisted of 'abilit[ies] to do something (either mental or physical)'. In a similar manner, Perrenoud (1999) had described competences as involving the ability to act in an effective way in a defined situation by making use of knowledge (cited in González-Bernal, 2008, p. 75).

\section{Competences and task-based language teaching}

As I said above, the competences curricular model implied narrowing the gap between educational outcomes and processes by striking a balance between the two concepts. As such, it has provided language education in general, and the FL subject in particular, with its prevalent pedagogical framework: namely, task-based language teaching (TBLT) or the task-based approach (Calvert \& Sheen, 2015; Ellis, 2009; Lambert, 2010; Littlewood, 2009; Long, 2000; Long \& Norris, 2004; Pica, 2008; Skehan, 1998). Within the FL educational field, Lambert (2010) argued that tasks were'the valid conceptual and pedagogic unit of analysis for organizing instruction' (p. 100), whereas Calvert and Sheen (2015) recently underlined the consensus derived from 'the growing empirical literature [...] that tasks have positive effects on second language (L2) learning' (p. 2). As is well known, TBLT built on Canale and Swain's 
(1980) original intuition that language cannot be learnt directly but only indirectly - that is, through communication - and hence encouraged learners to engage in meaningful (real or artificial) communicative situations or tasks (Lorenzo, 2014). 'Communicative Language Teaching is based on the communicative competence model that comprises grammatical, sociolinguistic and strategic competences' (Shawer, 2010, p. 334). In this context, task fulfilment did not only demand that learners develop specific competences - for example: being able to ask for directions, apologizing or asking for help or more complex tasks such as acquiring academic knowledge or project work - but also enabled teachers to conduct contextualized (and hence meaningful) inquiries into language forms, by responding to the needs which the students came across during the process (Long \& Norris, 2004, p. 599). TBLT reflected the widespread understanding that FL education was not about teaching language forms as much as about helping learners acquire different communicative competences (Canale \& Swain, 1980) by participating in contextualized tasks. Ideally, these should be the backbone of the language curricula. 'For the learner', Dautry (2004) said, 'the issue is thus no longer knowledge but skill (more precisely, the "ability to do"), no longer knowing different forms of the past tense but being able to tell a story in the past' (p. 454).

Insofar as teaching through competences included dimensions of the educational process, it is not surprising that Alarcon Leiva et al. (2014) considered it the touchstone to build curricula that had finally freed themselves from the objectives vs. process dichotomy. This would also be true for TBLT in FL education: by embedding communicative tasks in the learning situation, the FL learning process became richer, more meaningful and significant, and obtained a communicative justification which went beyond the attainment of the language goals (Calvert \& Sheen, 2015; Foster, 2009; Skehan \& Foster, 2001).

\section{Principles of procedure: an alternative framework for process curricula}

This article takes a completely different course from the competences model when it comes to justifying a process model of curriculum for the FL school subject. As mentioned before, it takes after Stenhouse's (1981) reformulation of Peters' principles of procedure as the backbone for curriculum design and development, as much as from subsequent work carried out by Elliott $(1991,1998,2007)$ and McKernan $(2007,2008)$ over this pedagogical line of thought. The essential idea lying behind these authors can be described thus: instead of embedding the objectives in the educational process to the point of making objectives and processes nearly indistinguishable (as teaching by competences does), educators should bolster the autonomy of the educational process and distinguish it clearly from pre-established outcomes of any kind, whether content and behavioural objectives or competences.

Originally, Stenhouse based this decision on the need for education to find a specific justification for itself; after all, objectives provided a social reason for education (Schwab, 2013), not an educational one. That is, they represented what society regarded as necessary and valuable for the new generations to learn; they were essential from an economic, professional or even civic point of view - they were even necessary for society to advance. Another way of seeing it is that they imposed adult behaviours on children (Apple, 1986, p. 69). Yet, apart from this social justification, whatever went on inside the classroom had to be worthwhile in itself and for the children, and not only on account of the contents, behaviours, competences, etc., which they allowed students to attain and enact as adults in social life. According to Elliott (1998), Stenhouse wished to design curricula that yielded 'public information about 
the quality of processes and procedures in schools: conceived in terms of their consistency with educational aims and values rather than their productivity in generating predetermined learning outcomes' (p. 41). 'Educational ends', Elliott (2007) emphasized, 'constitute intrinsic criteria for judging what is to count as a worthwhile educational process' (p. 19).

Let me formulate this basic intuition in a different way by focusing on the deficits of the competence model. The latter had brought the teaching and learning process closer to the outcomes it wished to attain, but in doing so it had created a new problem: not only had competences distorted the very concept of process by equating it with a series of objectives, sub-objectives, sub-sub-objectives, etc., which, rather than unifying the education process seemed to divide it into infinite moments (see for example Dörnyei, Muir, and Ibahim's (2014) account of language curricula as a series of extrinsic proximal, distant, and intermediate goals), but in addition to this, the nature of these learning outcomes, whether content-related ones or competences, remained external to the intrinsic aims of the educational logic. As a result, Stenhouse saw the need for education to find for itself a specific justification, one which was different from - albeit not necessarily incompatible with - the indirect justification it already obtained from the important service it paid to society by making students attain 'the necessary repertoire of skills, knowledge and attitudes to feel empowered to be able to cope and be successful not only in their future school career but beyond that when they leave school' (Byrne et al., 2013, p. 339). This quest for a specific, directly educational justification coincided with a more nuanced and sophisticated definition of the educational process, one which no longer saw it simply as a sum of tasks which the educator carried out and evaluated in relation to pre-established outcomes.

\section{Process curriculum and educational experience}

How was this link between the educational process and its justification established? McKernan's (2008) close reading of Stenhouse's original proposal clarifies the course taken: 'The curriculum needs to be seen as a continuous educational experience: a process, rather than a product. That is, as an educational experience, rather than a behavior, or outcome of that experience' (p. 6).'The underpinning idea,' he had stated two pages before, 'is to develop a curriculum based on a theory of educational experience, rather than behavior change' ( $p$. 4). By connecting the nature or meaning of the educational process with the learners' experience - not with the objectives, as task-based teaching did - , Stenhouse justified curricula on the grounds of the educational experiences they afforded the people who took part in them - not only (but mainly) the learners; also the teachers. Especially illustrative of this move was his reformulation of the basic question which, in his opinion, should inspire curriculum design: from 'Will it work?' - which underlay the objectives model - to 'Can this curriculum offer something worthwhile?' (Stenhouse, 1981, p. 105).

Nowhere but in the internal qualities of the experience undergone by the people taking part in the curriculum did education realize its most essential purpose and potential. This experience had to be an educational one, not one of any kind. It had therefore nothing to do with students' reproducing the experiences they brought from home (Young, 2013), or with having fun, feeling comfortable or relaxed in the classroom, etc., all of which situations could of course take place but none of which translated the essence of the experience and of the corresponding educational justification which, as will be seen next, Stenhouse strove so hard to define. 


\section{Induction into knowledge through principles of procedure: the epistemological justification for education}

Stenhouse's (1981) final understanding of the qualities of a worthwhile educational experience came down to the idea of education providing learners with 'induction into knowledge' (p. 82). This was precisely what a process curriculum based on principles of procedure was supposed to attain. This did not imply an objective as much as an educational purpose, or an aim (pp. 38-39; see also Reiss and White (2014)). 'It is possible to select content for a curriculum unit without reference to student behaviors or indeed to ends of any kind other than that of representing the form of knowledge in the curriculum,' Stenhouse (1981) claimed.

This is because a form of knowledge has structures; it involves procedures, concepts and criteria. Content can be selected to exemplify the most important procedures, the key concepts and the areas and situations in which the criteria hold. (p. 85)

At this point, one cannot fail to appreciate the similarities between Stenhouse's emphasis on 'induction into knowledge' and Young's (2013) stress on the 'learners' entitlement to knowledge, which summarizes the guiding principle behind his proposal for curriculum design and development. Yet one cannot fail to appreciate, either, how Stenhouse's plan was less preoccupied with the content of the consolidated knowledge than with the method through which such knowledge was produced. As shown by the quote above, principles of procedure encapsulated the methodological and epistemological framework of any given area of knowledge which the ordering of school subjects tended to replicate - Mathematics, History, Biology, Philosophy, Languages, etc. Rather than the contents, these frameworks established the conditions under which the people working in those disciplines had been able to produce knowledge and make advances in their fields; they defined the ways of acting and thinking which had enabled every contribution to culture or expansion of knowledge to take place. Each discipline had generated them along its history and in relation to specific subject matters, and on many occasions experts had had to exercise them against the grain of other social imperatives. Hence, McKernan's (2007) understanding of these principles as 'in-built standards of excellence' which enjoyed a certain degree of autonomy (unlike competences, which are transferable across disciplines and contexts). Pedagogically speaking, this autonomy guaranteed that academic 'disciplines $\mathrm{d}[\mathrm{id}]$ not require justification based on objectives' (p. 4), insofar as the curriculum and the whole educational process could be grounded on these principles. 'If there are disciplines of knowledge which are structured and have logical procedures and tests for truth,'Stenhouse (1981) wondered, 'is not the aim of teaching a discipline to explore the structure, to get some bearings within it?' (p. 36).

This was what induction into knowledge implied. Curricula that allowed students to experience induction into knowledge should organize tasks that granted them the possibility to regulate their thoughts and actions inside the classroom by the same standards, logical procedures and tests for truth that drove the experts working in those disciplines. Thus, as in Young's (2013) knowledge-based approach, the intrinsic justification of education was also an epistemological one. As philosopher Immanuel Kant used to tell his students, according to Reichardt (1765-1770), who attended his classes from 1765 to 1770:'Not philosophy, but rather philosophizing, is what my lectures are supposed to teach.'

Compared with this process model, curricula which were 'broken down into objectives' were simply 'destructive to the epistemology of the subject knowledge' (McKernan, 2008, p. 75). They 'mistake the nature of knowledge' (Stenhouse, 1981, p. 79). Instead of setting 
principles of procedure to structure the learners' forms of action and thought without imposing specific outcomes on their agency, objectives curricula set a list of learning outcomes from the outset which had to be attained because they were requested by society. 'It is the objectives and the objectives alone [...] that dictate the pupil-experiences that make up the curriculum. It is these in their turn that dictate the specific methods to be employed by the teachers and specific material helps and appliances and opportunities to be provided', claimed Bobbit (1920, p. 142, cited in Au, 2011, p. 26). The degree to which these outcomes were attained or not was then scrutinized and assessed for accountability purposes, and as long as they were reached the quality of the learners' experience and the worth of the whole educational process were validated in retrospect, regardless of its internal qualities (Tanner, 2013). The process model of curriculum, by contrast, was guided by principles of procedure that, if respected, would automatically validate the outcomes that issued from their application, as its organic and coherent developments (Elliott, 1991, p. 142). This did not mean that the outcomes of the educational process were unimportant, or that they did not have to be assessed and evaluated by the teacher. Stenhouse' only claim was that they should not be set beforehand, as a list of objectives to be pursued and the sole manifestation of which would either justify or delegitimize the whole educational endeavour. As McKernan (2008) stated, 'we are attempting to elicit responses from students but not to predetermine and define the outcome of that response' (p. 168).

\section{Formulating principles of procedure for the FL classroom}

Following on from this line of reasoning, this section contends that language education in general, and FL education in particular, would benefit a lot from formulating disciplinespecific principles of procedure and allowing their corresponding curricula to be guided by them. As mentioned in the Introduction, to the best of my knowledge, this endeavour remains untested. The most paradigmatic curricular proposals designed within this specific process model, such as'Man: A course of study' (Education Development Center, 1972) or the Humanities Project (Elliott, 2007, pp. 15-28; Humanities Project, 1970; Stenhouse, 1981, pp. 130-141) were all applied to the social sciences and centred on topics such as the impact of poverty, race relations, immigration, etc. More recently, McKernan (2008) and a group of graduate students at East Carolina University outlined a process curriculum which translated general epistemological and methodological practices of the social sciences into pedagogical principles through which the teacher would induce his or her learners into the knowledge of poverty (p. 169).

Concerning the FL area, the prescriptive nature of its curricula - the fact that they tend to consist of a list of content outcomes - may have discouraged educators from even considering the potential benefits that may ensue from using this process approach. Despite the fact that many educators and language researchers have contributed theoretical and practical accounts which implicitly convey principles of procedure - and this article will accordingly build on them - , the truth is that no explicit or conscious attempt has been made in this direction. Notwithstanding this fact, I believe significant advantages may be derived from the development of such a set of principles for the FL subject, most important among which would be to provide teachers who follow communicative and task-based orientations to language teaching with an additional criterion to better justify, choose, design and implement their curricular tasks. Let us analyse this issue. 


\section{The insufficiency of the communicative approach in FL education}

If one school subject has been plagued with many of the general problems diagnosed in the previous sections, this has been the FL one. Even if one is willing to concede, as Littlewood (2009) did, that TBLT has become a widespread pedagogical orientation in this educational area - Carless (2009) even speaks of TBLT as the current 'orthodoxy' (p. 66 cited in Ur, 2013, p. 469), a point which is open to contention - , FL education would still share the shortcomings attributed to the competency-based approach early on in this article. In a recent volume addressing EFL primary and secondary education from a European perspective, researchers found that the main motivational problem lay in 'what students find as monotonous language activities in the EFL classroom, a state of demotivation that many teachers find frustrating' (Doiz, Lasagabaster, \& Sierra, 2014, p. 118). As a matter of fact, the curricular and pedagogical limitations assigned to competence-based approaches in EFL teaching are often expressed as curricula that - first - remain inattentive to the need for language education to have an intrinsic justification (while they tend to emphasize the professional one, as shown in Gray (2010)); and - secondly - betray a pedagogical reading of the process dimension which equates it with - or at least renders it subservient to - the attainment of the learning objectives. Thus, even when the latter are conceived as competencies and task outcomes, they reflect a narrow social rationalization of the learning process of a FL.

The current EFL curriculum for Secondary Education in my own region in Spain provides a clear example of this. Whereas it allegedly assumes the recommendations issued by the European Common Frame of Reference (Council of Europe, 1991) for teachers to organize their teaching around 'communicative tasks' (Conselleria d'Educació, 2007, p. 30546) it makes no mention whatsoever of intrinsic educational standards that might have been worth considering for the subject. Through four brief paragraphs in the Preamble, EFL education is justified on account of the 'socioeconomic changes and great technological progress' undergone by Spain in recent decades; by the country's'geographic location and economic evolution' in the services, agricultural, and industrial sectors, and finally by the need to foster an 'image of European citizenship' (p. 30546). After this brief Preamble, the curriculum turns into a never-ending list of language objectives which show an exclusive 'focus on form' (Long, 2000), as evinced by the following list of elements extracted from the third block of contents: 'Greeting formulae. Verbs be and have got. Personal pronouns, demonstratives and interrogatives. Articles. Singular and plural forms of nouns. Word order: adjective + noun. Adjectives in predicate position. Possessives. The Saxon genitive. Prepositions: on, in, from, at, etc. Telephone numbers' (p. 20532) ... so the curriculum runs, as if teachers could actually use these content-objectives as a point of departure for designing worthwhile communicative tasks.

The above example reveals the insufficiency of the communicative criterion to contribute to the immanent educational interest of FL curricular tasks (Van Deusen-Scholl, 2008, p xiv), to fulfil 'educational, rather than merely communicative, goals' (Kramsch, 2008, p. 10). There is a risk that the communicative rationale, per se, misses the educational raison d'être. Communication may be too wide and vague a term to allow us to discriminate between tasks which are educationally worthwhile and those which are not. After all, there are many forms of communication, and not all of them are educational; in the same way that day in and day out, a language user is involved in communicative situations which are uninteresting, 
conventional or academically irrelevant, so there is a risk that curricular communicative tasks which lack any academic interest or educational potential might intrude on the FL subject.

As I and the rest of the participants in the collaborative action research project described below were soon to realize, while the framework formed by communicative competence and its pedagogical counterpart, communicative language teaching (Shawer, 2010), may have succeeded in ruling out transmission-oriented forms of pedagogy (ones which opted for the direct teaching of language forms), an educational problem remains when it comes to deciding over the intrinsic worth of a given curricular activity.

\section{A framework for developing process curricula for the FL subject}

In order to solve this problem, this article follows the same process it did in diagnosing it in the first place. The solution comes from transcending the narrow scope of FL theory and practice and connecting it with ideas and concepts from general pedagogical thought (Villacañas de Castro, 2013). Apart from the work of educators immersed in process-model curriculum development, this move was also inspired by scholars from within the field of ESL and EFL education. For example, in a recent text which insisted on the post-method era experienced by TESOL, Ur (2013) suggested that, instead of following specific methods that 'tend to focus predominantly on issues related specifically to language teaching', teachers should rather follow and design 'their own situated methodologies [...] largely grounded in general principles and practice shared by teachers of a variety of different subjects'. Such situated methodologies, she added, 'are based on general theories of teaching and learning, not only those that have to do with language pedagogy specifically' ( $p$. 470). The same willingness to acknowledge the worth of general pedagogical frameworks for the FL and SL contexts, and to adapt the latter to those, can be found in Cummins (2007) proposal for teaching for cross-language transfer, which re-enacted general principles which, as shown in the research of Bransford, Brown, and Cocking (2000), simply defined optimal conditions to foster any kind of learning: namely, 'engaging prior understanding', 'integrating factual knowledge with conceptual frameworks' and 'taking active control over the learning process through meta-cognitive strategies'(cited in Cummins, 2007, p. 231). Bransford et al. (2000) had assessed their realization in History, Mathematics and Science classrooms, whereas Cummins (2007) applied them to SL and FL educational contexts without failing to articulate them with field-specific literature.

In my case, the main aim of formulating principles of procedure for the EFL subject is to provide a tentative framework for educators to assess the intrinsic educational worth of the tasks included in their language curricula and, if necessary, to transform and reshape them in the fashion embodied by this process-model. Principles of procedure could be used as a guide for teachers to make sure that they facilitate learners' induction into language knowledge, i.e. that the latter engage in and realize the same forms of thought and action which characterize the people who make important contributions to that field of knowledge and practice.

What induction into FL knowledge might mean, and which principles of procedure would be capable of realizing it, is what must be analysed next. Let us explore the first question first. If, as stated above, principles of procedure connect with the deep epistemological structure of a discipline - 'subjects [...] are re-contextualized from disciplines which are a society's primary source of new knowledge' (Young, 2013, p. 114) - , then any FL subject 
should build its own principles up on the general area of language studies. Instead of focusing on native-like competence, as the communicative approach largely does (Holme, 2003; Kramsch, 2008; Moirano, 2012), any attempt to formulate principles of procedure for $\mathrm{FL}$ education should reflect the epistemological diversity of the field. In other words, induction into FL knowledge should allow students to approach and experiment with the manifold dimensions implied by any language. This was precisely what I found in Cummins, Early, and Stille's (2011) 'Literacy Expertise Framework' (p. 33, adapted from Cummins, 2001, p. 125), and hence also the reason why it provided the point of departure for the list of principles of procedure for the FL class which is presented below. Despite the fact that it was written from a pedagogical perspective, as an attempt to 'express in a concrete way the kinds of instructional emphases and language interactions required to build students'literacy expertise' (p. 32), the framework bore witness to whole-language (Richards \& Rodgers, 2014) or macro-instructional approaches (Kagan \& Dillon, 2008) which, as such, retained for the FL and SL classroom much of the epistemological richness which characterizes the study of language. Furthermore, the fact that it was originally built for TESOL is desirable as it suggests that my proposal, based on it, is not completely unrealistic.

Actually, the key pedagogical assumption behind 'Literacy Expertise Framework' was that language teachers should design tasks which adopted a triple focus on meaning, language and use. Under the first focus, these authors included the need to'make content comprehensible' and 'develop students' capacity for critical literacy'; under focus on language, 'promoting awareness of language forms and uses' and 'enabling students to analyse language forms and uses critically'; whereas focus on use consisted of 'enabling students to use language to: generate new knowledge, create literature and art, and act on social realities' (p. 33).

The list presented below builds closely on the wealth of epistemological perspectives that characterizes framework. Just as McKernan's (2008, p. 169) example mentioned above, it attempts to translate it into pedagogical principles that enable teachers to induce their learners into FL knowledge. Since these standards are designed to provide FL education with an intrinsic educational justification, they have been introduced with a conditional clause. Thus, FL educators will contribute to making the FL subject educationally worthwhile if they allow learners to ...

- investigate how language works as a system;

- investigate how society impacts on language;

- experiment how to generate new knowledge through language;

- experiment how to create literature and art through language (feel like poets and writers);

- experiment how to act on and transform social realities through language.

The epistemological and the pedagogical foundation of this framework should be emphasized. The first two criteria integrate sub-disciplines that are internal to the study of language, such as linguistics - defined precisely in the Merriam Webster Encyclopaedia (2015) as the 'study of the nature and structure of language' - , sociolinguistics, which is 'concerned with the relationship between language use and social variables' (Lee McKay, 2008, p. 17), and critical literacy. Through the last three criteria, by contrast, the framework already interacts with extralinguistic disciplines such as science, aesthetics or politics, which are too closely tied to academic language for a FL process curriculum not to welcome them inside the classroom through concrete dimensions of the language tasks. This interaction already conveys the 
pedagogic articulation which this article envisions between the principles of procedure and task-based approaches to FL. Actually, the relationship between the two concepts is considered reciprocal: on the one hand, the specific aims of FL education cannot but realize themselves in and through curricular tasks - 'the valid conceptual and pedagogic unit of analysis for organizing instruction,' as Lambert (2010, p. 100) argued - whereas, on the other, language tasks cannot justify themselves educationally if they don't allow learners to enact, to some extent, the principles of procedure that the above pedagogical criteria would hypothesize for the class.

\section{Tasks derived from the framework: a collaborative research project}

As has been said in the Methodology section, the main research experiences that led me to write this article occurred during the 2013-2014 and 2014-2015 academic years, when two different groups of undergraduate student-teachers, whose final practicum placement I was supervising, joined me in a collaborative action research project focused on the degree to which the aforementioned principles of procedure were applicable to primary EFL education. At first, these undergraduate students generally had some mixed feelings about this project. On the one hand, they were intrigued by the possibility of EFL teachers making the subject educationally worthwhile by allowing learners to experiment with generating new knowledge through the EFL and also create literature and art. On the other hand, they also expressed logical doubts, uncertainties and concerns, especially in relation to whether their primary students' EFL level would enable them to actively participate and succeed in these tasks, and become engaged in the educational experience they were being offered. In order to deal with some of these early negative reactions and ameliorate their effects, our initial conversations frequently dwelled on the difference between the cognitive and the linguistic dimensions of the FL learning process, as well as on the complexity of articulating them harmoniously, a possibility which was soon identified as one of the basic challenges (and research aims) of our project - i.e. the fact that, when acting as teachers, they would have to scale down the EFL linguistic demands of the tasks without lowering the cognitive standards to the point of making them uninteresting or boring for the learners. Accordingly, we discussed a number of strategies to overcome this problem.

Firstly, introducing multimodality in the EFL classroom (mainly visual resources) was viewed as an essential tool in order to scaffold the EFL learners in the process of completing the language tasks. Likewise, together with the undergraduate students in the 2013-2014 action research, I came up with a simple and original instruction to help them explain to their primary EFL learners the basic purpose of the tasks designed to enact the principles of procedure, a strategy which I used from the outset with the 2014-2015 action research group. It was inspired by an example found in Gibbons (2009) in which the author informed her group of English learners that, in the context of a given activity, they would have to 'speak as scientists' (p. 114). We called this the 'as if' strategy in our project, as it consisted of telling the primary students that they would have to write as if they were writers and poets, or research as if they were scientists, etc., depending on the specific principles of procedure involved. The student-teachers felt confident that through this basic directive not only would they be able to get the purpose of their EFL activities across to their primary pupils, but also provide them with the chance to assume responsibility for new and significant roles that entailed demanding academic skills. 
Finally, we also addressed the need to embrace a democratic and horizontal orientation to the curriculum (Banegas, 2014), one which started off from and respected the learners' reality and experiences but which, in addition, encouraged them to express their opinions, interests, likes and dislikes, especially in relation to the choice of the topics or themes around which the principles of procedure would be enacted in the FL class.

By the end of these action research projects, most of the undergraduate students had been successful in enacting FL principles of procedure through tasks that, to a certain extent, incorporated these strategies. They had the opportunity to share their experiences in our joint meetings and in their final report on their practicum placement, on which the following paragraphs are based. Due to space constraints, I will only focus on three of the resulting educational proposals. Haurra, one of the undergraduate students from the 2013-2014 group, designed a workshop called My way to school, which was implemented with EFL learners aged eight and nine. The pupils had to write in English a list of the different buildings which they came across each morning on their way from home to school, and include them in a simplified map showing the itinerary they followed daily. By adopting the kind of bird'seye view found in the GoogleMaps application (which Haurra accessed through the class computer to show her pupils what their home to school journeys looked like on a map), the children had to divide a large piece of card into several streets and blocks of buildings, and include on them some of the institutions they came across each morning, as their parents or other family members accompanied them to school, on foot or by car. Once the maps were completed, and their routes drawn on top, the children had to describe their route in a written form and include information about the buildings shown. This meant they had to make use of terms that signalled direction ('I turn left, I turn right, I walk ahead ...') and vocabulary related with the buildings, institutions and spaces they came across. But they did so with a research goal in mind - to produce knowledge and gain awareness about their immediate surroundings, and about an essential activity which they carried out daily, and which brought together their home and school contexts (Figure 1).

That same academic year, Alexandra and the in-service teacher who supervised her practicum in the school conducted a project which allowed EFL learners to experiment how to generate new knowledge and also create literature and art through the English language (i.e. act as if they were poets and writers). They designed a series of activities for primary students of all ages around International Women's Day, the final outcome of which consisted of each student writing a short biographical text, in English, on a woman who played or had played a significant role in society. The pupils were free to decide which woman to choose, based on their interests, and in the end, women from all walks of life were represented. But more important than this final biographical text was the way in which the whole workshop was organized, because the teacher planned activities through which her pupils extended their immediate life experiences, and transferred the emotional and cultural meaningfulness attached to them to their work with the FL. She started by asking her pupils to bring photos of any female member in their family (mother, grandmother, etc.) and to write a short descriptive paragraph about her. Poems were then composed for Mother's Day based on these paragraphs, and only after this did the group start to research the lives of significant women through proper academic work. All the work was finally brought together on posters, which were hung on the walls for all the school to read (Figure 2).

Finally, lovis - from the 2014-2015 action research group - gave primary EFL learners the chance to 'create literature and art through language' while inventing their own video 


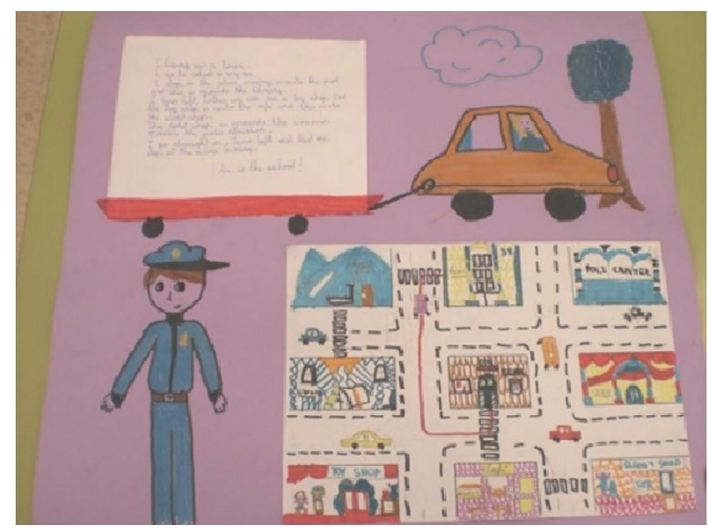

Figure 1. My way to school.

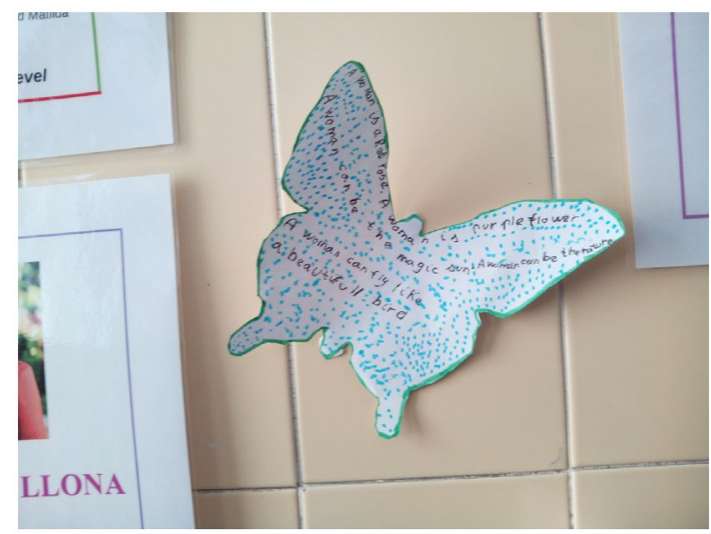

Figure 2. Mother's Day poem on school wall.

game heroes. Thanks to this, 11-and 12-year-old pupils put themselves in the shoes of video game programmers and designed fantastic characters that reflected some of their authors' true or desired qualities. lovis thus channelled the learners' interests and creativity into the English classroom and boosted their language learning through multimodality, by including learner-made drawings at different points in the workshop. He also used checklists for the primary EFL learners to gradually build the information which they later rendered into paragraph form, when they composed longer texts that described the heroes' qualities. Figure 3 shows an example of the poster that each learner produced by the end of this workshop.

Contrary to what was the case with the tasks these student-teachers often came across during their practicum placements (based as they were on course books and other predesigned FL materials, the richness and academic interest of which tended to be irregular), these three curricular tasks revealed a common focus on meaning and an underlying desire to be complex and educationally worthwhile. Of course, they also involved a potential challenge for the teachers-to-be and the learners who took part in them, but one which was worth taking on. From a teacher perspective, the tasks placed important demands on the undergraduates'self-confidence, imagination and ability to manage the workload, especially 


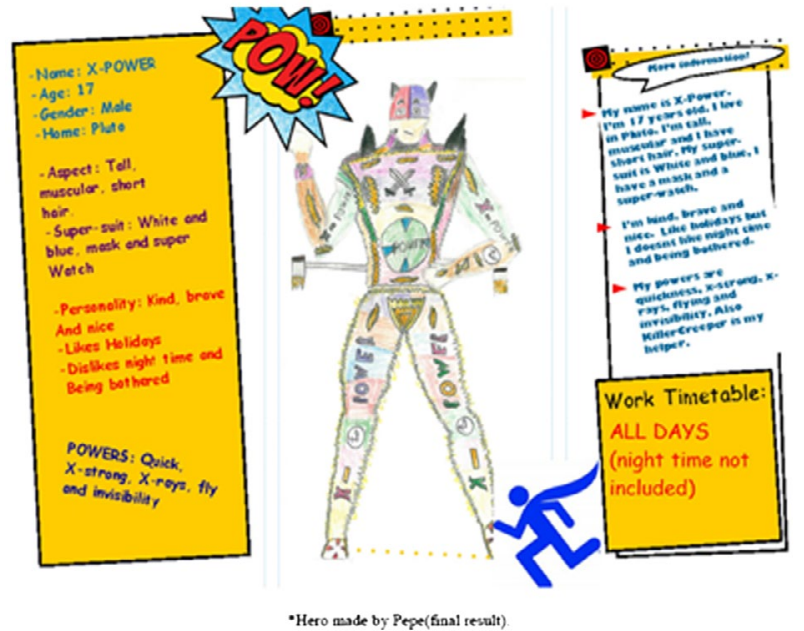

Figure 3. Heroes in the EFL classroom.

taking into account the limited amount of time allocated to EFL studies in the general curriculum. In this regard, they referred to having experienced a gradual change of focus once they started to design their own curricular tasks, from being absorbed in a short-term perspective to adopting a mid- or long-term one. Thus, they claimed to have invested more time and effort in imagining, designing and preparing the workshops in advance, and according to the FL principles of procedure, than during the lessons themselves, which were more learner-oriented and thus allowed them to adopt roles other than those strictly related to instruction or correction purposes - for example, to work hand in hand with the EFL learners in the classroom or to act as researchers, two roles which they found appealing and essential for the success of the tasks they had proposed.

Another key variable the student-teachers paid attention to was the need to integrate the linguistic and cognitive dimensions in a suitable manner, for example by encouraging the learners to create their own visual artefacts to accompany their texts. As we have seen in the three examples described above, enriching the context of the tasks with self-made visual props and establishing ties with the learners' home realities were instrumental in this regard. The results were clearly positive. To the extent that the tasks enacted principles of procedure, they were in consonance with Stenhouse's (1981) assertion that 'one can think in a discipline at elementary as well as advanced levels of study' (p. 38). This thesis has been rephrased in the SL and FL context as the need for teachers not to lower the cognitive level of the FL tasks to suit their learners' FL level, but rather to do exactly the opposite: take advantage of the interest and engagement that cognitively demanding tasks awake in $\mathrm{FL}$ learners to indirectly boost their FL learning (Gibbons, 2009). All of these tasks'ensure[d] that the linguistic level of the learners did not determine or reduce [their] cognitive processing' (Coyle, 2008, p. 102). From a learner perspective, it was clear that the EFL pupils gradually had to abandon the passive attitude which normally prevailed during the book-centred EFL classes, and take the risk of engaging (emotionally and cognitively) with the demanding tasks that the undergraduate students presented to them, and thus ended up discovering the worthwhile artistic and linguistic experiences that awaited them. 


\section{Conclusion}

'A curriculum,' Stenhouse (1981) explained, 'is an attempt to communicate the essential principles and features of an educational proposal in such a form that it is open to critical scrutiny and capable of effective translation into practice' (p. 4). In keeping with this line of reasoning, Stenhouse suggested that educational hypotheses had to take the form of curricular proposals which, in turn, would be assessed through case studies capable of conveying their true educational worth. I am fully aware that, contrary to Stenhouse's expectations, this article has not presented a fully detailed curricular proposal but rather a set of concrete tasks which however exemplify the possibility of coming up with a process model of curriculum for the EFL classroom. These tasks were based on a basic framework for teachers to develop such process-oriented curricular proposals, and its five criteria should be considered as a tentative translation of the varied and multilayered epistemological dimension which inheres in the field of language studies, albeit one that revealed itself to be in consonance with the pedagogical underpinnings of current whole-language approaches to FL instruction. The intuition that the epistemological and the pedagogical perspectives could be reconciled, and that bringing them together would produce a beneficial outcome in the form of principles that guaranteed that FL tasks were worthwhile in themselves, acted as the original catalyst for this research. I believe this intuition has been proved right by the resulting framework. And, even though it might be argued that the student-teachers that took part in this collaborative research could have arrived at similar tasks by following other methodological orientations, the essential justification for these FL principles of procedure lies precisely in that they were able to inspire, by themselves, the curricular proposals described above (among others which I have not been able to include), all three of which succeeded in turning around the rigid, superficial and uninteresting interactions that prevailed in these EFL classrooms and created, instead, an educational experience that was worthwhile for the learners. As anyone who is acquainted with the reality of this school area surely knows, experiences as those favoured by these workshops are the exception, not the norm. Taking all the evidence into account, there are sound reasons for believing that FL principles of procedure afford (despite the obstacles and challenges) a promising framework for teachers to base their curricular decisions on, precisely because they address the need to find a specific educational justification for EFL tasks.

Obviously, before this intuition and its promise can be fully borne out by more empirical evidence, Stenhouse's (1981) suggestion should be followed and this basic framework converted into entire curricular proposals that can be shared and assessed by the FL educational community. This is a logical step which derives from this text, and I hope to develop it in future articles. At this early stage of my ongoing research, it is already evident that intrinsic educational worth and its impact on meaningful learning, engagement and motivation will become essential criteria to validate such process-oriented proposals.

Apart from designing more curricular proposals, and assessing their impact on the FL class, it would also be helpful for language educators to come up with their own list of principles of procedure for the FL subject, based on their own epistemological assumptions about the discipline. The tentative nature of the list above has already been emphasized. One can only expect benefits to arise from this endeavour; should language educators try to unearth and make explicit in their own words the deepest tenets which rule their field of knowledge and practice, a huge step would be made in the direction of bridging the gap between theory 
and practice, research and teaching. By presenting and experimenting with their own lists of principles of procedure for the FL subject - by openly speaking their minds about how to make FL education something worthwhile in itself and the FL subject a subject worth studying - language teachers could see themselves as something other than instructors who must realize certain social goals, in the form of learning objectives. On the contrary, they would provide themselves with internal criteria to allow them to give a conscious orientation and coherence to their teaching, even if they left the curricular learning goals unmodified. One can suppose that, as more and more teachers make their own principles of procedure public and, hence, their own conceptions of what can make their subject worth studying, these principles of procedure for the FL classroom could be refined and translated into more adequate and meaningful curricular proposals.

\section{Acknowledgements}

I would like to thank the Editor and the anonymous reviewers of Journal of Curriculum Studies for helpful suggestions concerning the early versions of the manuscript.

\section{Disclosure statement}

No potential conflict of interest was reported by the author.

\section{Funding}

This work was supported by the Conselleria d'Educació, Cultura i Esport of the Generalitat Valenciana (Spain) [grant number GV/2015/050]; Vicerrectorat de Polítiques de Formació i Qualitat Educativa of the Universitat de València (Spain)[grant number UV-SFPIE_RMD15-314975].

\section{Notes on contributor}

Luis S. Villacañas de Castro is an assistant professor in the Department of Language and Literature Education, Universitat de València; Facultat de Magisteri, Av. Tarongers 4, 4006, València, Spain; email: Luis.villacanas@uv.es. His research interests lie where language education (especially EFL) and critical pedagogy intersect. He has recently published Critical Pedagogy and Marx, Vygotsky and Freire: Phenomenal Forms and Educational Action Research in Palgrave Macmillan.

\section{ORCID}

Luis S. Villacañas de Castro (iD) http://orcid.org/0000-0002-4121-254X

\section{References}

Alarcon Leiva, J., Hill, B., \& Frites, C. (2014). Educación basada en competencias: hacia una pedagogía sin dicotomías [An education based on competences: Towards a pedagogy free of dychotomies]. Educaçao \& Sociedade, 35, 569-586.

Alexander, R. (2004). Still no pedagogy? Principle, pragmatism and compliance in primary education. Cambridge Journal of Education, 34, 7-33.

Apple, M. (1986). Ideology and curriculum. London: Routledge \& Kegan Paul.

$\mathrm{Au}, \mathrm{W}$. (2011). Teaching under the new Taylorism: High-stakes testing and the standardization of the 21 st century curriculum. Journal of Curriculum Studies, 43, 25-45. 
Banegas,D.L.(2014). Democratizing didactictransposition:Negotiations betweenlearnersandtheirteacher in a secondary school. Latin American Journal of Content and Language Integrated Learning, 7, 1-26. doi: 10.5294/laclil.2014.7.2.1

Bobbit, J. F. (1920). The objectives of secondary education. In R. J. Gress (Ed.), Curriculum: Frameworks, criticism, and theory (pp. 135-144). Richmond, CA: McCrutchan.

Bolhuis, S., \& Voeten, M. (2001). Toward self-directed learning in secondary schools: What do teachers do? Teaching and Teacher Education, 17, 837-855.

Bransford, J. D., Brown, A. L., \& Cocking, R. R. (2000). How people learn: Brain, mind, experience and school. Washington, DC: National Academy Press.

Byrne, J., Downey, C., \& Souza, A. (2013). Planning a competence-based curriculum: The case of four secondary schools in England. Curriculum Journal, 24, 335-350.

Calvert, M., \& Sheen, Y. (2015). Task-based language learning and teaching: An action-research study. Language Teaching Research, 1-19.

Canale, M., \& Swain, M. (1980). Theoretical bases of communicative approaches to second language teaching and testing. Applied Linguistics, I, 1-47.

Carless, D. (2009). Revisiting the TBLT versus P-P-P debate: Voices from Hong Kong. Asian Journal of English Language Teaching, 19, 49-66.

Carr, W., \& Kemmis, S. (1986). Becoming critical: Education, knowledge and action research. London: The Falmer Press.

Conselleria d'Educació. (2007, July 20 ). Retrieved January 20, 2015, from http://www.docv.gva.es/ datos/2007/07/24/pdf/2007_9717.pdf

Council of Europe. (1991). Common European framework of reference for languages: Learning, teaching, assessment. Strasbourg: Language Policy Unit.

Coyle, D. (2008). CLIL - A pedagogical approach from the European perspective. In N. Van Deusen-Scholl \& N. H. Hornberger (Eds.), Encyclopedia of language and education. Volume 4: Second and foreign language education(pp. 97-112). Philadelphia, PA: Springer.

Cumming, A. (2009). Language assessment in education: Tests, curricula, and teaching. Annual Review of Applied Linguistics, 29, 90-100.

Cummins, J. (2001). Negotiating identities: Education for empowerment in a diverse society. Los Angeles: California Association for Bilingual Education.

Cummins, J. (2007). Rethinking monolingual instructional strategies in multilingual classrooms. Canadian Journal of Applied Linguistics, 10, 221-240.

Cummins, J., Early, M., \& Stille, S. (2011). Frames of reference: Identity texts in perspective. In J. Cummins \& M. Early(Eds.), Identity texts. The collaborative creation of power in multilingual schools (pp. 21-43). London: Trentham \& Institute of Education Press.

Dautry, C.-L. (2004). Objectives in language teaching and learning. In M. Byram (Ed.), Routledge encyclopedia of language teaching and learning (pp. 452-455). New York, NY: Routledge.

de Landsheere, V., \& de Landsheere, G. (1975). Définir les objectifs de l'education [Defining objectives in education]. Paris: PUF.

Doiz, A., Lasagabaster, D., \& Sierra, J. M. (2014). Giving voice to the students. What (de)motivates the in CLIL classes? In D. Lasagabaster, A. Doiz, \& J. M. Sierra (Eds.), Motivation and foreign language learning. From theory to practice (pp. 117-138). Amsterdam: John Benjamins.

Dörnyei, Z., Muir, C., \& Ibahim, Z. (2014). Directed motivational currents: Energising language learning by creating intense motivational pathways. In D. Lasagabaster, A. Doiz, \& J. M. Sierra (Eds.), Motivation and foreign language learning. From theory to practice (pp. 9-31). Amsterdam: John Benjamin.

Education Development Center. (1972). Man: A course of study. Social Education, 36, 742-744.

Elliott, J. (1991). Action research for educational change. Milton Keynes: Open University Press.

Elliott, J. (1998). The curriculum experiment. Meeting the challenge of social change. Buckingham: Open University Press.

Elliott, J. (2007). Reflecting where the action is. The selected works of John Elliott. Oxon: Routledge.

Ellis, R. (2009). Task-based language teaching: Sorting out the misunderstandings. International Journal of Applied Linguistics, 19, 221-246.

Foster, P. (2009). Task-based language learning research: Expecting too much or too little? International Journal of Applied Linguistics, 19, 247-263. 
Fuhrman, S., \& Elmore, R. F. (2004). Redesigning accountability systems for education. Columbia, SC: Teachers College Press.

Gibbons, P. (2009). English learners, academic literacy, and thinking. Learning in the challenge zone. Portsmouth: Heinemann.

González-Bernal, M. I. (2008). Alcance y límites de un currículo basado en competencias [Range and limits of a competences-based curriculum]. Educación y Educadores, 11, 69-102.

Gray, J. (2010). The branding of English and the culture of the new capitalism: Representations of the world of work in English language textbooks. Applied Linguistics, 31, 714-733.

Holme, R. (2003). Carrying a baby in the back: Teaching with an awareness of the cultural construction of language. In M. Byram \& P. Grundy (Eds.), Context and culture in language teaching and learning (pp. 18-31). Clavedon: Multilingual Matters.

Humanities Project. (1970). The humanities Project: An introduction. London: Heinemann.

Husch, D. (2007). Assessing No Child Left Behind and the rise of neoliberal education policies. American Educational Research Journal, 44, 493-518.

Kagan, O., \& Dillon, K. (2008). Issues in heritage language learning in the United States. In N. Van Deusen-Scholl \& N. H. Hornberger(Eds.), Encyclopedia of language and educaation. Volume 4: Second and foreign language education (pp. 143-156). Philadelphia, PA: Springer.

Kramsch, C. (2008). Applied linguistic theory and second/foreign language education. In N. van DeusenScholl \& N. H. Hornberger (Eds.), Encyclopedia of language and education. Volume 4: Second and foreign language education (pp. 3-16). Philadelphia, PA: Springer.

Lambert, C. (2010). A task-based needs analysis: Putting principles into practice. Language Teaching Research, 14, 99-112.

Lee McKay, S. (2008). Sociolinguistics and language education. In N. van Deusen-Schol \& N. H. Hornberger (Eds.), Encyclopedia of language and education, 2nd edition, Volume 4: Second and foreign language education (pp. 17-28). New York, NY: Springer+Business Media LLC.

Littlewood, W. (2009). Process-oriented pedagogy: Facilitation, empowerment, or control? ELT Journal, $63,246-254$.

Long, M. (2000). Focus on form in task-based language teaching. In R. D. Lambert\& E. Shohamy (Eds.), Language policy and pedagogy (pp. 191-196). Philadelphia, PA. : John Benjamins.

Long, M. H., \& Norris, J. M. (2004). Task-based teaching and assessment. In M. Byram (Ed.), Routledge encyclopedia of language teaching and learning (pp. 597-603). New York, NY: Routledge.

Lorenzo, F. (2014). Motivation meets bilingual models. Goal-oriented behavior in the CLIL classroom. In D. Lasagabaster, A. Doiz, \& J. M. Sierra (Eds.), Motivation and foreign language learning. From theory to practice (pp. 139-155). Amsterdam: John Benjamins.

Mager, R. F. (1962). Preparing objectives for programmed instruction. Belmont, CA: Fearon.

Male, B., \& Waters,M. (2014). Designing the school curriculum. In A. Pollard (Ed.), Readings for reflective teaching in schools (pp. 214-216). London: Bloomsbury.

Markee, N. (1997). Second language acquisition research: A resource for changing teachers' professional cultures?. The Modern Language Journal, 81, 80-93.

McKernan, J. (2007). The action inquiry seminar: Education in democratic classrooms. College Quarterly, $10(4), 1-6$.

McKernan, J. (2008). Curriculum and imagination. Process theory, pedagogy and action research. Oxon: Routledge.

Merriam Webster Encyclopaedia. (2015, January 28). Linguistics. Retrieved from http://www.merriamwebster.com/concise/encyclopaedia\%20britannica

Moirano, M. C. (2012). Teaching the students and not the book: Addressing the problem of culture teaching in EFL in Argentina. Gist. Education and Learning Research Journal, 6, 71-96.

Newby, D. (2004). Syllabus and curriculum design. In M. Byram (Ed.), Routledge encyclopedia of language teaching and learning (pp. 590-594). New York, NY: Routledge.

Nunan, D. (1988). Syllabus design. Oxford: Oxford University Press.

O'Sullivan, Í. (2007). Enhancing a process-oriented approach to literacy and language learning: The role of corpus consultation literacy. ReCALL, 19, 269-286.

Perrenoud, P. (1999). Construir competencias desde la escuela [Building competences from school]. Santiago de Chile: Dolmen. 
Peters, R. S. (1966). Ethics and education. London: George Allen and Unwin.

Pica, T. (2008). Task-based instruction. In N. van Deusen-Schol \& N. H. Hornberger (Eds.), Encyclopedia of language and education, 2nd edition, Volume 4: Second and foreign language education (pp. 71-82). New York, NY: Springer+Business Media LLC.

Reichardt, J. F. (1765-1770). Kant in the classroom. Materials to aid the study of Kant's lectures. Retrieved January 12, 2015, from http://www.manchester.edu/kant/lectures/lecturesListAccounts. htm\#Braxein 1

Reiss, M. J., \&White, J. (2014). An aims-based curriculum illustrated by the teaching of science in schools. The Curriculum Journal, 25, 76-89.

Richards, J. C., \& Rodgers, T. S. (2014). Approaches and methods in language teaching (3rd ed.). Cambridge: Cambridge University Press.

Schwab, J. (2013). The practical: A language for curriculum. Journal of Curriculum Studies, 45, 591-621.

Shawer, S. (2010). Communicative-based curriculum innovations between theory and practice: Implications for EFL curriculum development and student cognitive and affective change. The Curriculum Journal, 21, 333-359.

Skehan, P. (1998). Task-based instruction. Annual Review of Applied Linguistics, 18, 268-286.

Skehan, P., \& Foster, P. (2001). Cognition and tasks. In P. Robinson (Ed.), Cognition and second language instruction (pp. 183-205). Cambridge: Cambridge University Press.

Skourtou, E., Kourtis-Kazoullis, V., \& Cummins, J. (2006). Designing virtual learning environments for academic language development. In J. Weiss, J. Nolan, \& J.Hunsinger(Eds.), The international handbook of virtual learning environments (pp. 441-467). Dordrecht: Springer.

Stenhouse, L. (1981). An introduction to curriculum research and development. London: Heinemann.

Stoks, G. L. (1996). Modern languages: Learning, teaching, assessment A common European framework of reference. Guide for curriculum developers. Strasbourg: Council of Europe.

Takayama, K. (2013). OECD, 'Key competencies' and the new challenges of educational inequality. Journal of Curriculum Studies, 45, 67-80.

Tanner, D. (2013). Race to the top and leave the children behind. Journal of Curriculum Studies, 45, 4-15. Taylor, L. (2014). General language proficiency (GLP): Reflections on the 'issues revisited' from the perspective of a UK examination board. Language Assessment Quarterly, 11, 136-151.

Tyler, R. (1949). Basic principles of curriculum and instructio. Chicago: University of Chicago Press.

Thomson, P., \& Gunter, H. (2009). Students' participation in school change: Action research on the ground. In S. Noffke \& B. Somekh (Eds.), The SAGE handbook of educational action research (pp. 409-419). Los Angeles, CA: Sage.

Ur, P. (2013). Language-teaching method revisited. ELT Journal, 67 (4), 468-474. doi:10.1093/elt/cct041

Van Deusen-Scholl, N. (2008). Introduction to volume 4: Second and foreign language education. In N. Van Deusen-Scholl \& N. H. Hornberger (Eds.), Encyclopedia of language and educaation. Volume 4: Second and foreign language education (pp. xiii-ix). Philadelphia, PA: Springer.

Van Els, T. (2004). Planning for foreign language teaching. In M. Byram (Ed.), Routledge encyclopedia of language teaching and learning (pp. 465-470). New York, NY: Routledge.

van Lier, L. (1996). Interaction in the language curriculum. London: Longman.

Villacañas de Castro, L. S. (2013). Teaching English as a foreign language in accordance with Socialconstructivist pedagogy. Tejuelo. Revista de Didáctica de la Lengua y la Literatura, 17, 97-119.

Villacañas de Castro, L. S. (2015a). 'Why should I study English if I'm never going to leave this town?' Developing alternative orientations to culture in the EFL classroom through CAR. Review of Education, Pedagogy, and Cultural Studies, 37, 289-307.

Villacañas de Castro, L. S. (2015b). Critical pedagogy and Marx, Vygotsky and Freire: Phenomenal forms and educational action research. New York, NY: Palgrave Macmillan.

Young, M. (2013). Overcoming the crisis in curriculum theory: A knowledge based approach. Journal of Curriculum Studies, 45, 101-118. 